\title{
Role of intracellular calcium stores in hair-cell ribbon synapse
}

\author{
Manuel Castellano-Muñoz ${ }^{1 *+}$ and Anthony J. Ricci ${ }^{1,2}{ }^{*+}$ \\ ${ }^{1}$ Department of Otolaryngology, Stanford University School of Medicine, Stanford, CA, USA \\ ${ }^{2}$ Department of Molecular and Cellular Physiology, Stanford University School of Medicine, Stanford, CA, USA
}

\section{Edited by:}

Simona Tritto, Instituto di Ricovero e

Cura a Carattere Scientifico C.

Mondino, Italy

Reviewed by:

Enrique Soto, Universidad Autónoma de Puebla, Mexico

Francesco Moccia, University of Pavia, Italy

\section{${ }^{*}$ Correspondence:}

Manuel Castellano-Muñoz and

Anthony J. Ricci, Department of

Otolaryngology, Stanford University

School of Medicine, 300 Pasteur Dr.

Edwards Building, Room 145,

Stanford, CA 94304, USA

e-mail: mcastellano@stanford.edu;

aricci@stanford.edu

${ }^{\dagger}$ Manuel Castellano-Muñoz and

Anthony J. Ricci have contributed

equally to this work.
Intracellular calcium stores control many neuronal functions such as excitability, gene expression, synaptic plasticity, and synaptic release. Although the existence of calcium stores along with calcium-induced calcium release (CICR) has been demonstrated in conventional and ribbon synapses, functional significance and the cellular mechanisms underlying this role remains unclear. This review summarizes recent experimental evidence identifying contribution of $\mathrm{CICR}$ to synaptic transmission and synaptic plasticity in the CNS, retina and inner ear. In addition, the potential role of CICR in the recruitment of vesicles to releasable pools in hair-cell ribbon synapses will be specifically discussed.

Keywords: ribbon synapse, hair cell, calcium store, CICR, hearing, synaptic plasticity
Sensory transduction in the inner ear relies on the mechanoelectrical capabilities of hair cells, the sensory receptors in auditory and vestibular organs. Hair cells contain two differentiated compartments with distinct physiological roles: the mechanosensitive hair bundle and the basolateral membrane that includes specialized synaptic zones. The hair bundle is responsible for translating a mechanical vibratory input into an electrical current that, coupled with the basolateral complement of voltage and calcium activated ion channels, creates a receptor potential. The receptor potential drives synaptic output from ribbon synapses. Ribbons are vesicle-associated structures implicated in the modulation of trafficking and fusion of synaptic vesicles at presynaptic terminals (Heidelberger et al., 2002; Frank et al., 2010; Snellman etal., 2011). Ribbons are also postulated to be important for creating a large pool of primed vesicles and even perhaps recycling endosomes into reusable synaptic vesicles (Kantardzhieva etal., 2013). Calcium ions play critical but distinct roles in mechanotransduction, receptor potential modulation and synaptic transmission. Whereas $\mathrm{Ca}^{2+}$ defines the open probability of apical mechanotransduction channels in hair bundles (Farris et al., 2006; Johnson et al., 2011; Peng et al., 2013) and regulates basolateral membrane channels (Art and Fettiplace, 2006), $\mathrm{Ca}^{2+}$ levels allow the trafficking and exocytosis of neurotransmittercontaining synaptic vesicles at ribbon synapses (Moser etal., 2006). Evoked synaptic transmission is mediated by $\mathrm{Ca}^{2+}$ influx through voltage-dependent $\mathrm{Ca}^{2+}$ channels and is additionally modulated by release of $\mathrm{Ca}^{2+}$ from intracellular stores. In this review, we will discuss the potential contribution of intracellular stores and $\mathrm{Ca}^{2+}$-induced $\mathrm{Ca}^{2+}$ release (CICR) to synaptic transmission in central, retinal and hair-cell ribbon synapses. The potential role of CICR in the recruitment of vesicles to releasable pools in hair-cell ribbon synapses will also be addressed.

\section{CICR IN CENTRAL SYNAPSES}

Calcium is an essential player in multiple processes in excitable cells, including the release of neurotransmitter in neurosecretory (Penner and Neher, 1988; Tse et al., 1997), central neurons (Kuba, 1994), and sensory receptors (Thoreson, 2007). During synaptic transmission, the influx of extracellular $\mathrm{Ca}^{2+}$ from voltage-dependent $\mathrm{Ca}^{2+}$ channels allows the release of neurotransmitter through the recruitment and exocytosis of vesicles in the active zone of presynaptic terminals (Katz and Miledi, 1969; Neher, 1998). However, the release of neurotransmitter can also be triggered by $\mathrm{Ca}^{2+}$ released from intracellular organelles containing ryanodine receptors (RyRs) or inositol triphosphate receptors $\left(\mathrm{IP}_{3} \mathrm{Rs}\right)$ by an amplificatory process termed CICR. In addition, recent evidences point to a role for $\mathrm{Ca}^{2+}$ released by endolysosomal vesicles containing NAADP-gated two-pore channels in central synaptic transmission (Chameau et al., 2001; Calcraft et al., 2009; Zhu et al., 2010), though this mechanism remains to be investigated at ribbon synapses. CICR has a role in both presynaptic (Llano et al., 2000; Unni et al., 2004) and postsynaptic terminals (Savic and Sciancalepore, 1998; Llano et al., 2000; Emptage et al., 2001; Rose and Konnerth, 2001; Simkus and Stricker, 2002). In neurons, CICR is implicated in neuronal excitability, gene expression, synaptic plasticity and synaptic release (Bouchard et al., 2003; Verkhratsky, 2005; Parekh, 2008). Endoplasmic reticulum (ER) 
seems to be the intracellular $\mathrm{Ca}^{2+}$ store responsible for CICR in presynaptic terminals (Verkhratsky, 2005). The neuronal ER is a continuous network that spreads throughout the cell, including soma, axons, boutons, dendrites and spines (Berridge, 1998; Chen et al., 2014). Although not entirely conclusive, there are anatomical evidences for the presence of ER along with $\mathrm{IP}_{3} \mathrm{Rs}$ and RyRs in presynaptic terminals (Ungar et al., 1981; Mercurio and Holtzman, 1982; Ungar et al., 1984; Krijnse-Locker et al., 1995; Bouchard et al., 2003). Neuronal RyRs can be activated following $\mathrm{Ca}^{2+}$ influx through voltage-dependent $\mathrm{Ca}^{2+}$ channels or ionotropic glutamate receptors (Berridge, 1998). Despite the lack of a unified mechanistic model, presynaptic CICR is present in several neuronal types such as motor neurons (Erulkar and Rahamimoff, 1978; Soga-Sakakibara et al., 2010), sympathetic neurons (Hua et al., 1993), cerebellar basket cells (Galante and Marty, 2003), striatal neurons (Plotkin et al., 2013), thalamocortical neurons (Cheong et al., 2011), Purkinje cells (Llano et al., 2000), sensory neurons (Shmigol et al., 1995), and cochlear nucleus neurons (Kato and Rubel, 1999). The presence of action potential-evoked as well as spontaneous CICR has been demonstrated by pharmacological effects of ryanodine, caffeine and other drugs on presynaptic $\mathrm{Ca}^{2+}$ levels and postsynaptic currents. At presynaptic terminals, $\mathrm{Ca}^{2+}$ stores modulated action potential-evoked $\mathrm{Ca}^{2+}$ signals, regulating the efficacy of transmitter release (Galante and Marty, 2003; Collin et al., 2005). In hippocampal boutons, action potentials evoked large $\mathrm{Ca}^{2+}$ transients triggered by both influx from $\mathrm{Ca}^{2+}$ channels and $\mathrm{Ca}^{2+}$ released from internal stores (Emptage et al., 2001). The observation that the frequency of spontaneous miniature postsynaptic events (mEPSCs) was reduced when blocking CICR in cortical (Simkus and Stricker, 2002), hippocampal (Emptage et al., 2001), and cerebellar neurons (Llano et al., 2000; Bardo et al., 2002), suggested that spontaneous exocytosis requires $\mathrm{Ca}^{2+}$ release from internal stores (Emptage et al., 2001). In motor neuron terminals, CICR was primed by tetanic stimulation, increasing the frequency of spontaneous release events (Narita etal., 1998). In cerebellar interneuron-Purkinje cell synapses, spontaneous presynaptic $\mathrm{Ca}^{2+}$ transients, reminiscent of $\mathrm{Ca}^{2+}$ sparks in muscle, were reduced by ryanodine (Llano et al., 2000). Interestingly, large-amplitude miniature inhibitory postsynaptic currents (mIPSCs; maximinis) persisted in the presence of tetrodoxin, cadmium or $\mathrm{Ca}^{2+}$-channel toxins, suggesting the contribution of CICR to spontaneous presynaptic activity (Llano et al., 2000). In reciprocal synapses between retinal amacrine cells and rod bipolar cells, $\mathrm{Ca}^{2+}$ influx through amacrine cell AMPARs triggers the synaptic release of GABA through CICR (Chavez et al., 2006).

Unfortunately, the main caveat in the identification of the physiological role of CICR in synaptic transmission is that most experimental evidences exclusively rely on the effects of nonspecific pharmacological agents. In addition, these drugs have often opposite effects depending on the dose and exert both pre and post-synaptic effects, adding complexity to pharmacological results that lead to ambiguous conclusions (Barnes and Hille, 1989; Llano et al., 2000; Emptage et al., 2001; Rose and Konnerth, 2001; Bouchard et al., 2003; Collin et al., 2005; Bardo et al., 2006). In fact, different reports using similar pharmacological approaches have resulted in contradictory conclusions (Emptage et al., 2001; Carter et al., 2002; Lelli et al., 2003; Beurg et al., 2005; Cadetti et al., 2006; Suryanarayanan and Slaughter, 2006). An additional source of variability in the study of CICR relies on the existence of different isoforms of RyRs (Lanner et al., 2010). Furthermore, drugs used in the study of CICR can also alter other $\mathrm{Ca}^{2+}$ homeostatic mechanisms, such as store-operated $\mathrm{Ca}^{2+}$ entry (SOCE), which can also modulate neuronal (Emptage et al., 2001) and ribbon synaptic transmission (Szikra et al., 2008). Nevertheless, numerous evidences point to the existence of a bona fide physiological role for CICR in synaptic transmission, although the distinct mechanism remains unclear (Hua et al., 1993; Llano et al., 2000; Sharma and Vijayaraghavan, 2003; Collin et al., 2005; Gordon and Bains, 2005; Bardo et al., 2006).

\section{ROLE OF CICR IN CENTRAL SYNAPTIC TRANSMISSION}

In neurons and cardiac cells, CICR is a graded rather than an all-or-none phenomenon in which release of $\mathrm{Ca}^{2+}$ from stores increases in a graded fashion with increasing stimulus strength $\left(\mathrm{Ca}^{2+}\right.$ channel activation; Fabiato, 1985; Beuckelmann and Wier, 1988; Hua et al., 1993; Usachev and Thayer, 1997; Berridge, 1998). Additionally, neuronal regenerative CICR can also be observed by incubating with a sensitizing agent such as caffeine and applying suprathreshold electrical stimulation (Usachev and Thayer, 1997). Local $\mathrm{Ca}^{2+}$ nanodomains generated by activation of close $\mathrm{Ca}^{2+}$ channels are sufficient to induce $\mathrm{Ca}^{2+}$ release from the ER (Stern, 1992; Stern et al., 1999). $\mathrm{Ca}^{2+}$ influx and efflux microdomains may exist as separate identities in the ER. Presynaptically, such spatial distribution suggests that different active zones could activate RyRs independently to coordinate intracellular release through the lumen of the ER network (Friedman and Voeltz, 2011; Chen et al., 2014). This scenario is consistent with multiple coincident exocytic events triggered by $\mathrm{Ca}^{2+}$ stores instead of nearby $\mathrm{Ca}^{2+}$ channels. Multivesicular release and compound fusion of synaptic vesicles is reported in central neurons (Tong and Jahr, 1994; He et al., 2009). Presynaptic information can be linearly transmitted to the postsynaptic terminal through multivesicular release in those synapses where receptors are not saturated nor desensitized (Singer et al., 2004), thus supporting short-term synaptic plasticity (Oertner et al., 2002; Quinlan and Hirasawa, 2013). Moreover, multivesicular release caused large miniature postsynaptic currents (maximinis) as large as $1 \mathrm{nA}$ in cerebellar Purkinje cells (Llano et al., 2000). Ryanodine (100 $\mu \mathrm{M}$ ) decreased the amplitude and frequency of mIPSCs and selectively eliminated maximinis, indicating that presynaptic RyRs are involved in the generation of multivesicular release (Llano et al., 2000). Extracellular $\mathrm{Ca}^{2+}$ removal abolished the presence of these maximinis and reduced the mean amplitude of uniquantal mIPSCs, suggesting that presynaptic $\mathrm{Ca}^{2+}$ reduction leads to depletion of $\mathrm{Ca}^{2+}$ stores and disruption of multivesicular release (Llano et al., 2000).

Together with cytoplasmic $\mathrm{Ca}^{2+}$ buffering, extrusion through plasma membrane ATPases and uptake into organelles, release of $\mathrm{Ca}^{2+}$ from intracellular stores contributes to the control of cytoplasmic basal $\mathrm{Ca}^{2+}$ levels. However, $\mathrm{ER} \mathrm{Ca}{ }^{2+}$ levels further confer memory of previous activity (Berridge, 1998). The amount of releasable $\mathrm{Ca}^{2+}$ from neuronal ER is proportional to 
the $\mathrm{Ca}^{2+}$ load contained in its lumen, which in turn depends on the cytosolic $\mathrm{Ca}^{2+}$ levels (Sitsapesan and Williams, 1990; Hua et al., 1993; Garaschuk et al., 1997; Berridge, 1998; Krizaj et al., 1999). Furthermore, RyR sensitivity is augmented by high luminal $\mathrm{Ca}^{2+}$ levels (Fill and Copello, 2002). Therefore, the amount of $\mathrm{Ca}^{2+}$ sequestered in the ER may become larger after consecutive stimulation and dependent on the magnitude of prior release. Intracellular $\mathrm{Ca}^{2+}$ stores have a role in neuronal synaptic plasticity (Zucker, 1989). At neuromuscular junctions, inhibitors of mitochondrial $\mathrm{Ca}^{2+}$ uptake and release blocked post-tetanic potentiation (Tang and Zucker, 1997). Nevertheless, numerous experimental results suggests that the ER is a highly dynamic intracellular $\mathrm{Ca}^{2+}$ store ideally suited for regulating different forms of synaptic plasticity (Fitzjohn and Collingridge, 2002; Baker et al., 2013). In addition, CICR has been implicated in longterm forms of synaptic plasticity. Genetic or pharmacological disruption of RyRs enhanced long-term potentiation (LTP) and impaired long-term depression (LTD) in CA1 pyramidal neurons [Futatsugi et al., 1999; Nishiyama et al., 2000; but also see Qin et al. (2012)], suggesting that $\mathrm{Ca}^{2+}$ from intracellular stores may contribute to decrease the threshold for LTD expression (Reyes and Stanton, 1996). Since sustained moderate $\mathrm{Ca}^{2+}$ rise induces NMDAR-dependent depression of synaptic transmission, postsynaptic steady-state CICR might support LTD under continuous synaptic activity, maybe through the recruitment of a subpopulation of AMPAR-containing vesicles. According to this, NMDAR-dependent LTD required $\mathrm{Ca}^{2+}$ release from ryanodinesensitive stores in CA3-CA3 hippocampal synapses (Unni et al., 2004). Furthermore, the coupling of postsynaptic AMPARs and $\mathrm{Ca}^{2+}$ stores could adjust synaptic strength depending on the number of synchronically activated synapses, switching the direction of synaptic plasticity from LTP to LTD (Camire and Topolnik, 2014). Similarly, both pre and postsynaptic ryanodine-sensitive $\mathrm{Ca}^{2+}$ stores were necessary for LTD induction in hippocampal GABAergic synapses (Caillard etal., 2000). LTP is reported to rely on $\mathrm{IP}_{3}$ Rs in presynaptic ER of sympathetic ganglia synapses (Cong et al., 2004). Moreover, synaptic plasticity can be modulated by the control of $\mathrm{Ca}^{2+}$-dependent vesicle mobilization between different vesicle pools (Alabi and Tsien, 2012), a mechanism potentially regulated by presynaptic $\mathrm{Ca}^{2+}$ stores (Levitan, 2008).

Most synapses with low probability of release show synaptic facilitation, a short-term form of plasticity in which repeated stimulation leads to a transient increase in the probability of synaptic release. CICR can sustain paired-pulse facilitation (PPF), a form of plasticity lasting hundreds of milliseconds to seconds. During PPF, the amplitude of a second excitatory postsynaptic potential (EPSP) becomes larger than a first EPSP, a phenomenon often attributed to residual $\mathrm{Ca}^{2+}$ from the first pulse summing up with the second pulse (Katz and Miledi, 1968). In pyramidal hippocampal neurons, blocking CICR with ryanodine or cyclopiazonic acid (CPA) reduced the enhancement in the second stimulus when separated by tens of milliseconds (Emptage et al., 2001) suggesting that CICR may be the source of some residual calcium. Thapsigargin also suppressed synaptic facilitation during high-frequency stimulation in hippocampal synapses (Zhang et al., 2009), further pointing to a role of CICR in short-term plasticity. The recruitment of reserve vesicles near active zones could be the functional target of CICR, modulating synaptic strength and mediating certain forms of synaptic plasticity (Bardo et al., 2006). However, mobilization of vesicles from the reserve pool has also been attributed to $\mathrm{Ca}^{2+}$ leakage from mitochondrial stores (Billups and Forsythe, 2002; Storozhuk et al., 2005), suggesting that short-term vesicle mobilization can be modulated by multiple $\mathrm{Ca}^{2+}$ stores. Nevertheless, the role of CICR in short-term synaptic plasticity remains controversial (Carter et al., 2002), and more data are needed to clarify the role of CICR on the milliseconds-to-seconds time scale.

\section{CICR IN PHOTORECEPTOR RIBBON SYNAPSES}

Aside from central synapses, CICR also plays a role in ribbon synaptic transmission in the retina and inner ear. Ribbon synapses support fast and sustained transmission of graded inputs through multivesicular release of synaptic vesicles in unique presynaptic organelles called synaptic ribbons. The existence of CICR was demonstrated in rods and cones, the two types of photoreceptors (Krizaj etal., 1999; Suryanarayanan and Slaughter, 2006; Szikra and Krizaj, 2006). In rods, a depolarization-evoked intracellular $\mathrm{Ca}^{2+}$ rise spread from the active zone across the synaptic terminal and could be blocked by ryanodine, suggesting that CICR has a presynaptic role in retinal synaptic transmission (Cadetti etal., 2006). Blocking $\mathrm{Ca}^{2+}$ sequestration into the ER by thapsigargin and CPA, two sarco/ER $\mathrm{Ca}^{2+}$ ATPase (SERCA) inhibitors, decreased the magnitude of depolarizationevoked and caffeine-evoked presynaptic $\mathrm{Ca}^{2+}$ transients, pointing to the ER as the intracellular $\mathrm{Ca}^{2+}$ store involved in CICR at photoreceptors (Szikra and Krizaj, 2007). Although its physiological effect varies among preparations, ryanodine generally promotes RyR opening at low micromolar concentrations (around 1-5 $\mu \mathrm{M}$ ) whereas it blocks RyRs at higher concentrations (50-100 $\mu \mathrm{M}$; Verkhratsky, 2005). Ryanodine (10 $\mu \mathrm{M})$ increased cytoplasmic $\mathrm{Ca}^{2+}$ levels in somas and synaptic terminals of rods, consistent with its effect as RyR agonist (Babai et al., 2010b). Similarly, caffeine, which is known to sensitize RyRs to $\mathrm{Ca}^{2+}$, triggered a robust transient $\mathrm{Ca}^{2+}$ increase followed by prolonged reduction (Krizaj et al., 1999). Ryanodine $(20 \mu \mathrm{M})$ suppressed these caffeine-evoked effects (Krizaj et al., 1999). In addition, $\mathrm{Ca}^{2+}$ substitution by barium, a divalent ion which is poorly sequestered into stores (Kwan and Putney, 1990; Adachi-Akahane et al., 1996), also suppressed caffeine effects (Krizaj et al., 1999). Immunohistochemistry studies showed RyRs in terminals of cones and rods (Krizaj et al., 2003, 2004), along with partial colocalization between ER-containing $\mathrm{Ca}^{2+}$ ATPase SERCA2 and Ribeye, the most abundant protein in synaptic ribbons (Babai et al., 2010b). All these data support the existence of CICR in photoreceptors and point to a real function of $\mathrm{Ca}^{2+}$ stores in phototransduction. In addition to CICR, SOCE also contribute to ribbon synaptic transmission by regulating presynaptic $\mathrm{Ca}^{2+}$ homeostasis (Szikra et al., 2008, 2009).

Evidence for the role of presynaptic CICR in ribbon synaptic transmission was obtained at rod-horizontal cell (Cadetti et al., 2006) and rod-bipolar cell ribbon synapses (Suryanarayanan and Slaughter, 2006). Mitochondrial $\mathrm{Ca}^{2+}$ uptake occurs in 
photoreceptors and bipolar presynaptic terminals only after strong depolarization (Zenisek and Matthews, 2000; Krizaj et al., 2003; Wan etal., 2012). However, the major role of mitochondria near synaptic ribbons is to provide the energy needed to pump $\mathrm{Ca}^{2+}$ outside the terminal (Zenisek and Matthews, 2000; Linton et al., 2010). Unlike mitochondria, the ER is directly involved in presynaptic CICR at retinal ribbon synapses. Caffeine incubation elicited a brief depolarization followed by a progressive hyperpolarization in horizontal cells, suggesting that presynaptic caffeine-sensitive $\mathrm{Ca}^{2+}$ stores modulate neurotransmitter release at the ribbon synapse (Krizaj et al., 1999). Similarly, light-evoked currents in horizontal cells were reduced by ryanodine $(100 \mu \mathrm{M})$, demonstrating the importance of CICR in this synapse and suggesting a potential presynaptic site of action (Babai et al., 2010b). In paired recordings from rods, blocking CICR with ryanodine reduced the later portions of the horizontal cell EPSC (Cadetti et al., 2006; Suryanarayanan and Slaughter, 2006). This effect was more prominent after prolonged stimulation, pointing to a key role of CICR on the later components of synaptic release (Cadetti et al., 2006). Ryanodine also reduced the intraretinal b-wave, the bipolar cell-evoked component of electroretinogram (Babai et al., 2010b). Light-evoked postsynaptic currents in bipolar cells were abolished by $100 \mu \mathrm{M}$ ryanodine (Suryanarayanan and Slaughter, 2006). In rod-bipolar synapses, ryanodine reduced both phasic and sustained transmitter release at rod physiological potentials (Suryanarayanan and Slaughter, 2006). The predominant effect of ryanodine on the late part of the bipolar EPSCs at different rod potentials pointed to a direct physiological role of CICR in sustained exocytosis of synaptic vesicles at rod terminals. Moreover, caffeine addition while blocking presynaptic $\mathrm{Ca}^{2+}$ channels with cadmium, evoked EPSCs in bipolar cells (Suryanarayanan and Slaughter, 2006), suggesting that $\mathrm{Ca}^{2+}$ released from stores is capable of evoking EPSCs. In this view, continuous moderate activation of voltage-dependent calcium channels would activate CICR-dependent exocytosis of vesicles, whereas strong stimulation could trigger vesicle exocytosis directly due to abrupt larger calcium loads through voltage-dependent calcium channels. This hypothesis points to a role for CICR in the resupply of vesicles for exocytosis during continuous stimulation. The large spontaneous postsynaptic events observed in paired recordings likely represents coordinated release of multiple vesicles (Suryanarayanan and Slaughter, 2006). The frequency and amplitude of these spontaneous EPSCs was reduced by ryanodine, suggesting a role for CICR in coordinating multivesicular release (Suryanarayanan and Slaughter, 2006). Bipolar cells present two EPSC components in response to rod depolarization: a transient and a sustained component of slower onset. The sustained synaptic component was reduced by $100 \mu \mathrm{M}$ ryanodine or $5 \mathrm{mM}$ BAPTA, pointing to a role for CICR in the exocytosis of vesicles recruited from a reserve pool (Suryanarayanan and Slaughter, 2006). Addition of ryanodine $(100 \mu \mathrm{M})$ also reduced the size of the larger spontaneous EPSCs, thought to emerge from coordinated neurotransmitter release, suggesting the potential role of CICR in synchronizing the fusion of multiple vesicles (Suryanarayanan and Slaughter, 2006). Since the recruitment of vesicles involves sites located a few hundreds of nanometers from the $\mathrm{Ca}^{2+}$ channels, it is possible that vesicle trafficking is modulated by the summation of $\mathrm{Ca}^{2+}$ signals from multiple nanodomains. This would reduce noise from stochastic $\mathrm{Ca}^{2+}$ channel openings, improving the signal-to-noise ratio and allowing CICR to ultimately regulate sustained release. Alternatively, CICR could facilitate the coordinated fusion of vesicles far from the active zone. Extrasynaptic exocytosis of vesicles or prefusion of vesicles before reaching the active zone are alternative scenarios consistent with this idea. Supporting this view, long depolarization pulses (>200 ms) applied to rods evoked the exocytosis of vesicles located far from synaptic ribbons (Chen et al., 2013). These ectopic exocytic events were triggered by CICR, suggesting the potential contribution of ER to maintained synaptic release of vesicles (Chen et al., 2014). By contrast, ectopic ribbon-independent synaptic release in rod bipolar-AII amacrine cell synapses was independent on intracellular calcium stores (Mehta et al., 2014), suggesting differential CICR contributions to different types of ribbon synapses.

\section{CICR IN HAIR CELLS}

The release of $\mathrm{Ca}^{2+}$ from intracellular stores has been demonstrated in hair cells of different animals in auditory and vestibular organs, where pharmacological modulators of $\mathrm{Ca}^{2+}$ stores and RyRs exerted an effect on $\mathrm{Ca}^{2+}$ hotspot amplitude, $\mathrm{Ca}^{2+}$ basal levels, membrane ion channels or hair-cell membrane capacitance. Imaging and electrophysiological experiments showed the existence of CICR in hair cells of frog semicircular canal (Hendricson and Guth, 2002; Lelli et al., 2003), turtle auditory papilla (Tucker and Fettiplace, 1995; Schnee et al., 2011b), and mammalian inner hair cells (IHCs; Kennedy and Meech, 2002) and outer hair cells (OHCs; Lioudyno et al., 2004).

In vestibular hair cells of the frog semicircular canal, caffeine $(10 \mathrm{mM})$ increased intracellular $\mathrm{Ca}^{2+}$ levels, an effect that was diminished by ryanodine ( $40 \mu \mathrm{M}$; Lelli et al., 2003). Additionally, incubation with caffeine $(1 \mathrm{mM})$ potentiated depolarizationevoked $\mathrm{Ca}^{2+}$ transients in hair-cell hotspots of the semicircular canal. Conversely, ryanodine $(40 \mu \mathrm{M})$ reduced depolarizationevoked $\mathrm{Ca}^{2+}$ transients. In a minority of cells, caffeine $(500 \mu \mathrm{M})$ also evoked membrane capacitance increases whereas ryanodine $(40 \mu \mathrm{M})$ reduced voltage-dependent capacitance increases (Lelli et al., 2003). Interestingly, this reduction was more apparent after repeated stimulation. The presence of RyRs in vestibular hair cells was also suggested by immunohistochemical evidence (Perin et al., 2012). In addition, the contribution of CICR to hair-cell synaptic transmission was further confirmed at postsynaptic compartments. The dose-dependent reduction of semicircular canal afferent discharge after incubation of caffeine, ryanodine and thapsigargin suggested a physiological role for $\mathrm{Ca}^{2+}$ stores in vestibular synaptic transmission (Hendricson and Guth, 2002). Postsynaptically, caffeine $(20 \mathrm{mM})$ increased and ryanodine $(1 \mathrm{mM})$ decreased spontaneous action potentials in the vestibular nerve (Lelli et al., 2003). The complete reduction of multiunit vestibular afferent discharge after incubation of xestospongin $\mathrm{C}$ $(1 \mu \mathrm{M})$, an $\mathrm{IP}_{3} \mathrm{R}$ blocker, also pointed to the presence of pre or postsynaptic $\mathrm{IP}_{3}$-sensitive $\mathrm{Ca}^{2+}$ stores (Hendricson and Guth, 2002). Similarly, $\mathrm{IP}_{3} \mathrm{R}$ inhibitors and compounds that increase $\mathrm{IP}_{3}$ production modulated vestibular discharge in frog semicircular canal (Rossi et al., 2006). 
Hair cells of the basilar papilla, the auditory organ of reptiles, amphibians and birds also contain intracellular $\mathrm{Ca}^{2+}$ stores. BHQ $(50 \mu \mathrm{M})$, a specific blocker of ER CaATPase, and caffeine (20 mM) elevated $\mathrm{Ca}^{2+}$ levels throughout the cell (Tucker and Fettiplace, 1995; Tucker etal., 1996), confirming the presence of ER $\mathrm{Ca}^{2+}$ stores. BHQ and thapsigargin prolonged the duration of $\mathrm{Ca}^{2+}$-dependent SK currents (Tucker et al., 1996) and increased $\mathrm{Ca}^{2+}$-dependent inactivation of $\mathrm{L}$-type $\mathrm{Ca}^{2+}$ channels (Lee et al., 2007). These results confirm that $\mathrm{ER} \mathrm{Ca}^{2+}$ homeostasis has an influence near the hair-cell membrane and suggest that the $\mathrm{Ca}^{2+}$ buffering and releasing capabilities of the ER might be separated spatially to avoid functional interference. More recently, a non-linear rise in the intracellular $\mathrm{Ca}^{2+}$ levels obtained by high-speed $\mathrm{Ca}^{2+}$ imaging during prolonged depolarization further pointed to the existence of CICR (Schnee et al., 2011b; Figure 1A).

Intracellular $\mathrm{Ca}^{2+}$ stores were identified in IHCs of the mammalian cochlea. Inhibitors of $\mathrm{ER} \mathrm{Ca}^{2+}$ uptake such as BHQ $(100 \mu \mathrm{M})$, thapsigargin $(200 \mathrm{nM})$, or CPA $(30 \mu \mathrm{M})$ increased resting cytoplasmic $\mathrm{Ca}^{2+}$ levels and slowed the recovery time after brief depolarization in neonatal IHCs (Kennedy, 2002). An increase in intracellular $\mathrm{Ca}^{2+}$ baseline levels was also observed after $10 \mathrm{mM}$ caffeine application in adult guinea pigs IHCs (Beurg et al., 2005), but not after $5 \mathrm{mM}$ caffeine application in immature mice IHCs (Kennedy, 2002). Ryanodine $(20 \mu \mathrm{M})$ reduced both amplitude and rise rate of depolarization-evoked $\mathrm{Ca}^{2+}$ transients in neonatal IHCs (Kennedy and Meech, 2002), a result that could not be reproduced in IHCs from 14 to 18 days-old mice (Frank et al., 2009). The amplitude of $\mathrm{Ca}^{2+}$-dependent $\mathrm{K}^{+}$currents was reduced by ryanodine $(20-100 \mu \mathrm{M})$ or caffeine and thapsigargin $(1 \mu \mathrm{M})$, demonstrating that the activity of RyRs located in the ER modulate $\mathrm{Ca}^{2+}$ levels around plasma membrane channels in mature IHCs (Marcotti et al., 2004; Beurg et al., 2005). In fact, immungold-EM localized RyRs in the ER at the base of IHCs and cisternae of the basolateral membrane (Grant et al., 2006). Compound action potentials in the auditory nerve were reversibly inhibited by intracochlear perfusion of ryanodine $(50-100 \mu \mathrm{M})$, further confirming the physiological relevance of hair-cell CICR in synaptic transmission (Beurg et al., 2005). Substitution of $\mathrm{K}^{+}$by cesium $\left(\mathrm{Cs}^{+}\right)$in the intracellular pipette solution is often used in patch-clamp experiments to block $\mathrm{K}^{+}$conductances and isolate $\mathrm{Ca}^{2+}$ currents. Interestingly, $\mathrm{Cs}^{+}$reduced $\mathrm{Ca}^{2+}$ increase in IHCs by an unknown intracellular mechanism, apparently blocking CICR (Kennedy and Meech, 2002). However, this effect was not observed in basilar papilla hair cells (Schnee et al., 2011b).

Mammalian OHCs present a robust CICR mechanism associated to efferent innervation (Ashmore and Ohmori, 1990; Sridhar et al., 1997; Evans et al., 2000; Lioudyno et al., 2004; Grant et al., 2006). Similarly, application of ATP to the hair bundle of OHCs triggered the release of $\mathrm{Ca}^{2+}$ from $\mathrm{IP}_{3} \mathrm{R}$-containing apical intracellular stores (Mammano etal., 1999). In addition to their electromotile behavior that supports cochlear amplification of incoming sounds, OHCs support synaptic transmission to type II afferents in response to loud sounds (Brown, 1994; Weisz et al., 2012). A potential role for CICR in type II afferents synaptic transmission has never been experimentally addressed.

\section{ROLE OF CICR IN HAIR-CELL SYNAPTIC TRANSMISSION}

Despite the numerous reports demonstrating the presence of intracellular $\mathrm{Ca}^{2+}$ stores in hair cells, their precise physiological role has not been clarified (Tucker and Fettiplace, 1995; Evans et al., 2000; Hendricson and Guth, 2002; Kennedy, 2002; Lelli et al., 2003; Marcotti etal., 2004; Beurg et al., 2005). The observation that $\mathrm{Ca}^{2+}$ stores regulated extrasynaptic BK channels lead to the hypothesis that CICR could counteract elevated $\mathrm{Ca}^{2+}$ accumulation through BK channel activation to hamper synaptic transmission during sound overstimulation or ischemia (Beurg et al., 2005). Several lines of evidence, however, lead to the proposition that $\mathrm{Ca}^{2+}$ stores are involved in hair-cell ribbon synaptic transmission. Synaptic transmission in auditory hair cells is characterized by an unusual broad distribution in the size of postsynaptic EPSCs, a unique feature that likely originates from the synchronized fusion of synaptic vesicles. The large range of vesicle sizes observed could additionally be due to prefusion of synaptic vesicles (Schnee et al., 2013). In turtle hair cells, lowering external $\mathrm{Ca}^{2+}$ dramatically reduced the frequency and size of burst-like EPSCs (Schnee et al., 2013), but the potential contribution of $\mathrm{Ca}^{2+}$ released from intracellular stores to complex EPSCs remains to be experimentally tested. The open probability of voltage-dependent $\mathrm{Ca}^{2+}$ channels controls the transient changes in presynaptic $\mathrm{Ca}^{2+}$ levels, allowing fast conduction of transient auditory information in adult animals (Brandt et al., 2005; Fedchyshyn and Wang, 2005). Calcium stores set the open probability of L-type $\mathrm{Ca}^{2+}$ channels, potentially modulating spontaneous release from ribbon synapses (Lee et al., 2007). Inhibition of $\mathrm{ER} \mathrm{Ca}^{2+}$ pumps with BHQ or thapsigargin lead to faster and increased $\mathrm{Ca}^{2+}$ channel inactivation (Lee et al., 2007). Unlike $\mathrm{Ca}^{2+}$ channels in mammalian IHCs, $\mathrm{Ca}^{2+}$ channels in bird and turtle auditory hair cells were half inactivated at resting potentials (Schnee and Ricci, 2003; Lee et al., 2007), opening the possibility of a presynaptic control of synaptic plasticity through the regulation of $\mathrm{Ca}^{2+}$ channel inactivation by calcium stores. Despite the lack of evidence that $\mathrm{Ca}^{2+}$ stores are indeed located in close proximity to active zones, $\mathrm{Ca}^{2+}$ stores could modulate the $\mathrm{Ca}^{2+}$ concentration sensed near plasma membrane channels (Marcotti et al., 2004; Beurg et al., 2005). Therefore, although a physiological role for CICR in tonic synaptic transmission would appear to be more feasible, a contribution to phasic transmission cannot be ruled out.

Although the existence of CICR in hair cells has been ratified in different studies, a unifying theory that enlightens its physiological relevance in synaptic transmission is still missing. The recent development of new technologies is opening new avenues for the understanding of the role of CICR in synaptic transmission at hair-cell ribbon synapses (Schnee et al., 2011a; Castellano-Munoz et al., 2012). Dual sine capacitance experiments, which monitor vesicle fusion in real time, identified two different release components during prolonged depolarization (Schnee et al., 2011b). A first linear component, proportional to the $\mathrm{Ca}^{2+}$ load, was equivalent in size to the fusion of the pool of vesicles near the synaptic ribbon (Figure 1B). The onset of a later larger superlinear component was $\mathrm{Ca}^{2+}$-load dependent and resembled non-linear exocytic components reported in bipolar and chromaffin cells (Seward et al., 1996; Wan et al., 2010). This superlinear component 
A
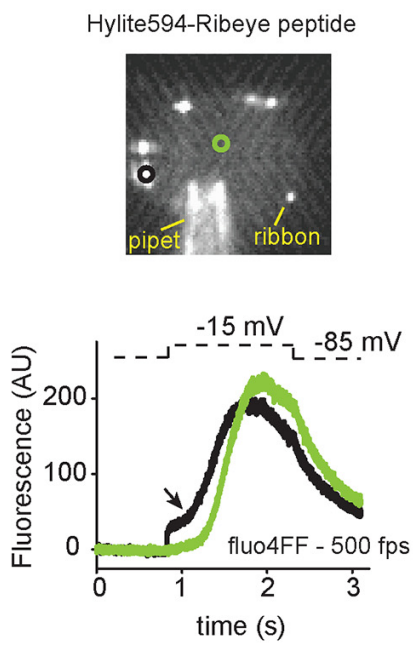

B
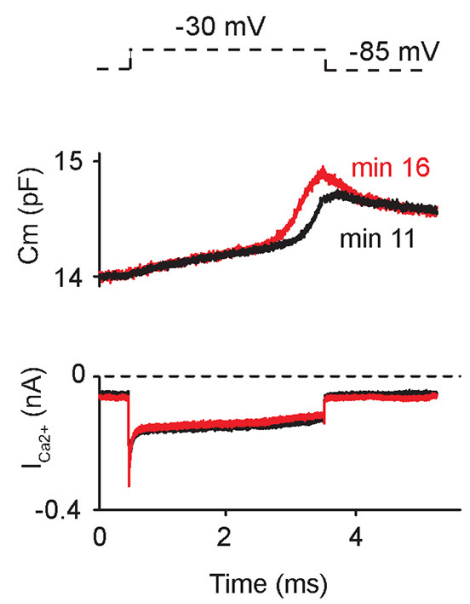

C

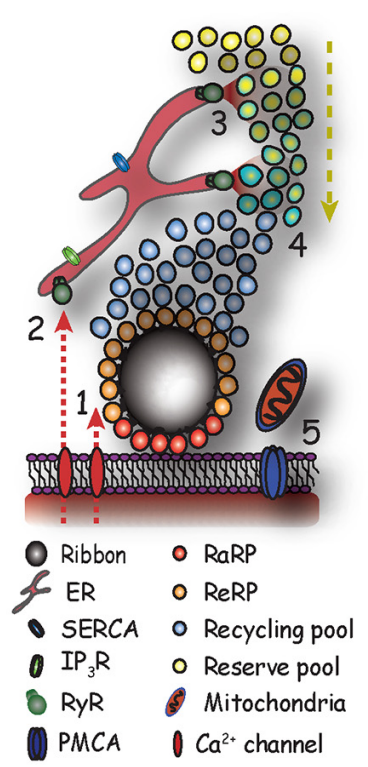

FIGURE 1 | (A) Hair cells show non-linear calcium increases during depolarization. Upper panel shows a swept-field confocal image of a single turtle auditory hair cell during patch clamp experiments.

Hylite594-conjugated ribbon-binding peptide in the internal solution defined the location of synaptic ribbons for subsequent calcium imaging recordings (note that peptide also binds unspecifically to the pipet). In the lower panel, calcium levels were monitored in response to depolarization by swept-field confocal microscopy at 500 frames per second (fps) using the low-affinity calcium dye fluo4FF. Black and green traces correspond to intracellular locations near and far from synaptic ribbons (circles in upper panel). Arrow points the onset of supralinear calcium rise. (B) Hair cells show time-variant exocytic enhancement. In an independent experiment, calcium currents and real-time membrane capacitance were obtained by dual sine capacitance methods. Eleven minutes after whole cell configuration, a superlinear release was first obtained during prolonged moderate depolarization (black trace). The onset of superlinear release was shifted by equivalent calcium load 5 min later (red trace). (C) Intracellular calcium stores could modulate the recruitment of vesicles to the plasma membrane. Calcium influx through L-type calcium channels triggers exocytosis of synaptic vesicles near the active zone (1). In parallel, calcium also activates RyRs (2), triggering the release of calcium stored in the ER at sites far from the ribbon (3). CICR allows the recruitment of vesicles from reserve pools to the vicinity of the ribbon (4). ( $E R=$ endoplasmic reticulum; $I P_{3} R=$ inositol triphosphate receptor; SERCA = sarco/endoplasmic reticulum calcium ATPase; RaRP = rapid releasable pool; ReRP $=$ readily releasable pool.) Mitochondria and calcium pumps maintain homeostatic calcium levels in cytoplasm (5). Arrows depict the direction of calcium influx and vesicle trafficking. could represent local buffer saturation leading to endosomal exocytosis (Coggins et al., 2007). Alternatively, this superlinear component could represent the fusion of newly recruited vesicles from the reserve pool evoked by CICR. In this scenario, reserve vesicles would be recruited by the release of stored $\mathrm{Ca}^{2+}$ at a distance of the active zones (Figure 1C). The two-kinetics behavior observed in capacitance recordings was paralleled by high-speed $\mathrm{Ca}^{2+}$ imaging experiments, where a supralinear intracellular $\mathrm{Ca}^{2+}$ rise was initiated at the vicinity of the ribbon and subsequently spread throughout the hair-cell cytoplasm (Figure 1A; Schnee et al., 2011b). In this view, it is conceivable that the exocytosis rate of vesicles from the readily releasable pool (RRP) with the terminal could be dependent on the $\mathrm{Ca}^{2+}$ load carried by voltage-dependent $\mathrm{Ca}^{2+}$ channels whereas the recruitment onset of reserve vesicles would be dependent on the onset of intracellular $\mathrm{Ca}^{2+}$ release (in turn triggered by plasma membrane $\mathrm{Ca}^{2+}$ influx). These two mechanisms would work in parallel to allow both phasic and tonic transmitter release for prolonged periods of time. In fact, the reduction in $\mathrm{Ca}^{2+}$ transients and exocytosis in hair cells by ryanodine application was more apparent after repeated stimulation, pointing to a CICR effect on the reserve pool of vesicles (Lelli et al., 2003). According to this idea, the existence of a $\mathrm{Ca}^{2+}$-dependent mechanism necessary to speed up the supply of new vesicles to the RRP during repetitive stimulation was proposed in neurosecretory cells (von Ruden and Neher, 1993; Voets et al., 1999). Central and ribbon synapses also contain calciumdependent mechanisms of vesicle replenishment (Dittman and Regehr, 1998; Stevens and Wesseling, 1998; Wang and Kaczmarek, 1998; Gomis et al., 1999; Shakiryanova et al., 2005) that play a direct role in encoding receptor potential into changes of sustained release rates (Jackman et al., 2009; Babai et al., 2010a). Moreover, the rate at which vesicles are recruited to the RRP depends on the levels of free $\mathrm{Ca}^{2+}$ and is modulated by synaptic activity (Stevens and Wesseling, 1998). These observations are consistent with a graded form of CICR being continuously triggered by $\mathrm{Ca}^{2+}$ influx, allowing the resupply of synaptic vesicles to active zones. Temporal regulation of vesicle recruitment may uncover new forms of presynaptic plasticity in hair-cell ribbon synapses (Figure 1B; Alabi and Tsien, 2012). It is important to note that the experimental dissection of the kinetics of both fusion and recruitment of reserve synaptic vesicles is only possible by the use of hyperpolarizing holding potentials used in patchclamp experiments (Schnee et al., 2011b). Unlike most central neurons, these potentials do not represent physiological resting conditions, since hair cells are moderately depolarized at rest due to the contribution of the mechanotransduction channel in the 
hair bundle. Conversely, more physiological holding potentials showed an overlapping of both components (Schnee et al., 2011b). Moreover, prepulse experiments using depolarization steps preceded by physiological resting potentials demonstrated an increase in exocytosis along with an increase in synaptic strength and a reduction in synaptic latency (Goutman and Glowatzki, 2011; Schnee et al., 2011b). All these experiments suggest that incessant $\mathrm{Ca}^{2+}$ influx allows hair-cell ribbon synapses to operate in a continuously facilitated mode at resting membrane potentials, thus optimizing the timing and size of postsynaptic responses in the auditory nerve. Future experiments are needed to address the nature and physiological relevance of both the exocytic superlinear component and the non-linear intracellular $\mathrm{Ca}^{2+}$ rises in the recruitment of vesicles mediated by CICR for hair-cell ribbon synaptic transmission.

\section{ACKNOWLEDGMENTS}

We want to thank Dr. Sandra Jurado for her insightful comments on this manuscript. This work was supported by a Dean's Postdoctoral Fellowship from Stanford School of Medicine and a Cajamadrid Foundation Fellowship to Manuel Castellano-Muñoz and NIDCD DC-009913 to Anthony J. Ricci.

\section{REFERENCES}

Adachi-Akahane, S., Cleemann, L., and Morad, M. (1996). Cross-signaling between $\mathrm{L}$-type $\mathrm{Ca}^{2+}$ channels and ryanodine receptors in rat ventricular myocytes. J. Gen. Physiol. 108, 435-454. doi: 10.1085/jgp.108.5.435

Alabi, A. A., and Tsien, R. W. (2012). Synaptic vesicle pools and dynamics. Cold Spring Harb. Perspect. Biol. 4, a013680. doi: 10.1101/cshperspect. a013680

Art, J. J., and Fettiplace, R. (2006). "Contribution of ionic currents to tuning in auditory hair cells," in Vertebrate Hair Cells, eds R. A. Eatock, R. R. Fay, and A. N. Popper (New York, NY: Springer).

Ashmore, J. F., and Ohmori, H. (1990). Control of intracellular calcium by ATP in isolated outer hair cells of the guinea-pig cochlea. J. Physiol. 428, 109-131.

Babai, N., Bartoletti, T. M., and Thoreson, W. B. (2010a). Calcium regulates vesicle replenishment at the cone ribbon synapse. J. Neurosci. 30, 15866-15877. doi: 10.1523/JNEUROSCI.2891-10.2010

Babai, N., Morgans, C. W., and Thoreson, W. B. (2010b). Calcium-induced calcium release contributes to synaptic release from mouse rod photoreceptors. Neuroscience 165, 1447-1456. doi: 10.1016/j.neuroscience.2009.11.032

Baker, K. D., Edwards, T. M., and Rickard, N. S. (2013). The role of intracellular calcium stores in synaptic plasticity and memory consolidation. Neurosci. Biobehav. Rev. 37, 1211-1239. doi: 10.1016/j.neubiorev.2013.04.011

Bardo, S., Cavazzini, M. G., and Emptage, N. (2006). The role of the endoplasmic reticulum $\mathrm{Ca}^{2+}$ store in the plasticity of central neurons. Trends Pharmacol. Sci. 27, 78-84. doi: 10.1016/j.tips.2005.12.008

Bardo, S., Robertson, B., and Stephens, G. J. (2002). Presynaptic internal $\mathrm{Ca}^{2+}$ stores contribute to inhibitory neurotransmitter release onto mouse cerebellar Purkinje cells. Br. J. Pharmacol. 137, 529-537. doi: 10.1038/sj.bjp.0704901

Barnes, S., and Hille, B. (1989). Ionic channels of the inner segment of tiger salamander cone photoreceptors. J. Gen. Physiol. 94, 719-743. doi: 10.1085/jgp.94.4.719

Berridge, M. J. (1998). Neuronal calcium signaling. Neuron 21, 13-26. doi: 10.1016/S0896-6273(00)80510-3

Beuckelmann, D. J., and Wier, W. G. (1988). Mechanism of release of calcium from sarcoplasmic reticulum of guinea-pig cardiac cells. J. Physiol. 405, 233-255.

Beurg, M., Hafidi, A., Skinner, L. J., Ruel, J., Nouvian, R., Henaff, M., et al. (2005). Ryanodine receptors and BK channels act as a presynaptic depressor of neurotransmission in cochlear inner hair cells. Eur. J. Neurosci. 22, 1109-1119. doi: 10.1111/j.1460-9568.2005.04310.x

Billups, B., and Forsythe, I. D. (2002). Presynaptic mitochondrial calcium sequestration influences transmission at mammalian central synapses. J. Neurosci. 22 , 5840-5847.
Bouchard, R., Pattarini, R., and Geiger, J. D. (2003). Presence and functional significance of presynaptic ryanodine receptors. Prog. Neurobiol. 69, 391-418. doi: 10.1016/S0301-0082(03)00053-4

Brandt, A., Khimich, D., and Moser, T. (2005). Few CaV1.3 channels regulate the exocytosis of a synaptic vesicle at the hair cell ribbon synapse. J. Neurosci. 25, 11577-11585. doi: 10.1523/JNEUROSCI.3411-05.2005

Brown, M. C. (1994). Antidromic responses of single units from the spiral ganglion. J. Neurophysiol. 71, 1835-1847.

Cadetti, L., Bryson, E. J., Ciccone, C. A., Rabl, K., and Thoreson, W. B. (2006). Calcium-induced calcium release in rod photoreceptor terminals boosts synaptic transmission during maintained depolarization. Eur. J. Neurosci. 23, 2983-2990. doi: 10.1111/j.1460-9568.2006.04845.x

Caillard, O., Ben-Ari, Y., and Gaiarsa, J. L. (2000). Activation of presynaptic and postsynaptic ryanodine-sensitive calcium stores is required for the induction of long-term depression at GABAergic synapses in the neonatal rat hippocampus. J. Neurosci. 20, RC94.

Calcraft, P. J., Ruas, M., Pan, Z., Cheng, X., Arredouani, A., Hao, X., et al. (2009). NAADP mobilizes calcium from acidic organelles through two-pore channels. Nature 459, 596-600. doi: 10.1038/nature08030

Camire, O., and Topolnik, L. (2014). Dendritic calcium nonlinearities switch the direction of synaptic plasticity in fast-spiking interneurons. J. Neurosci. 34, 38643877. doi: 10.1523/JNEUROSCI.2253-13.2014

Carter, A. G., Vogt, K. E., Foster, K. A., and Regehr, W. G. (2002). Assessing the role of calcium-induced calcium release in short-term presynaptic plasticity at excitatory central synapses. J. Neurosci. 22, 21-28.

Castellano-Munoz, M., Peng, A. W., Salles, F. T., and Ricci, A. J. (2012). Swept field laser confocal microscopy for enhanced spatial and temporal resolution in live-cell imaging. Microsc. Microanal. 18, 753-760. doi: 10.1017/S14319276120 00542

Coggins, M. R., Grabner, C. P., Almers, W., and Zenisek, D. (2007). Stimulated exocytosis of endosomes in goldfish retinal bipolar neurons. J. Physiol. 584, 853865. doi: 10.1113/jphysiol.2007.140848

Collin, T., Marty, A., and Llano, I. (2005). Presynaptic calcium stores and synaptic transmission. Curr. Opin. Neurobiol. 15, 275-281. doi: 10.1016/j.conb.2005. 05.003

Cong, Y. L., Takeuchi, S., Tokuno, H., and Kuba, K. (2004). Long-term potentiation of transmitter exocytosis expressed by $\mathrm{Ca}^{2+}$-induced $\mathrm{Ca}^{2+}$ release from thapsigargin-sensitive $\mathrm{Ca}^{2+}$ stores in preganglionic nerve terminals. Eur. J. Neurosci. 20, 419-426. doi: 10.1111/j.1460-9568.2004.03492.x

Chameau, P., Van De Vrede, Y., Fossier, P., and Baux, G. (2001). Ryanodine-, IP3and NAADP-dependent calcium stores control acetylcholine release. Pflugers. Arch. 443, 289-296. doi: 10.1007/s004240100691

Chavez, A. E., Singer, J. H., and Diamond, J. S. (2006). Fast neurotransmitter release triggered by Ca influx through AMPA-type glutamate receptors. Nature 443, 705-708. doi: 10.1038/nature05123

Chen, M., Krizaj, D., and Thoreson, W. B. (2014). Intracellular calcium stores drive slow non-ribbon vesicle release from rod photoreceptors. Front. Cell. Neurosci. 8:20. doi: $10.3389 /$ fncel.2014.00020

Chen, M., Van Hook, M. J., Zenisek, D., and Thoreson, W. B. (2013). Properties of ribbon and non-ribbon release from rod photoreceptors revealed by visualizing individual synaptic vesicles. J. Neurosci. 33, 2071-2086. doi: 10.1523/JNEUROSCI.3426-12.2013

Cheong, E., Kim, C., Choi, B. J., Sun, M., and Shin, H. S. (2011). Thalamic ryanodine receptors are involved in controlling the tonic firing of thalamocortical neurons and inflammatory pain signal processing. J. Neurosci. 31, 1213-1218. doi: 10.1523/JNEUROSCI.3203-10.2011

Dittman, J. S., and Regehr, W. G. (1998). Calcium dependence and recovery kinetics of presynaptic depression at the climbing fiber to Purkinje cell synapse. J. Neurosci. 18, 6147-6162.

Emptage, N. J., Reid, C. A., and Fine, A. (2001). Calcium stores in hippocampal synaptic boutons mediate short-term plasticity, store-operated $\mathrm{Ca}^{2+}$ entry, and spontaneous transmitter release. Neuron 29, 197-208. doi: 10.1016/S08966273(01)00190-8

Erulkar, S. D., and Rahamimoff, R. (1978). The role of calcium ions in tetanic and post-tetanic increase of miniature end-plate potential frequency. J. Physiol. 278, 501-511.

Evans, M. G., Lagostena, L., Darbon, P., and Mammano, F. (2000). Cholinergic control of membrane conductance and intracellular free $\mathrm{Ca}^{2+}$ in outer hair 
cells of the guinea pig cochlea. Cell Calcium 28, 195-203. doi: 10.1054/ceca. 2000.0145

Fabiato, A. (1985). Time and calcium dependence of activation and inactivation of calcium-induced release of calcium from the sarcoplasmic reticulum of a skinned canine cardiac Purkinje cell. J. Gen. Physiol. 85, 247-289. doi: 10.1085/jgp.85.2.247

Farris, H. E., Wells, G. B., and Ricci, A. J. (2006). Steady-state adaptation of mechanotransduction modulates the resting potential of auditory hair cells, providing an assay for endolymph $\left[\mathrm{Ca}^{2+}\right]$. J. Neurosci. 26, 12526-12536. doi: 10.1523/JNEUROSCI.3569-06.2006

Fedchyshyn, M. J., and Wang, L. Y. (2005). Developmental transformation of the release modality at the calyx of Held synapse. J. Neurosci. 25, 4131-4140. doi: 10.1523/JNEUROSCI.0350-05.2005

Fill, M., and Copello, J. A. (2002). Ryanodine receptor calcium release channels. Physiol. Rev. 82, 893-922. doi: 10.1152/physrev.00013.2002

Fitzjohn, S. M., and Collingridge, G. L. (2002). Calcium stores and synaptic plasticity. Cell Calcium 32, 405-411. doi: 10.1016/S01434160020 01999

Frank, T., Khimich, D., Neef, A., and Moser, T. (2009). Mechanisms contributing to synaptic $\mathrm{Ca}^{2+}$ signals and their heterogeneity in hair cells. Proc. Natl. Acad. Sci. U.S.A. 106, 4483-4488. doi: 10.1073/pnas.08132 13106

Frank, T., Rutherford, M. A., Strenzke, N., Neef, A., Pangrsic, T., Khimich, D., et al. (2010). Bassoon and the synaptic ribbon organize $\mathrm{Ca}^{(2)}+$ channels and vesicles to add release sites and promote refilling. Neuron 68, 724-738. doi: 10.1016/j.neuron.2010.10.027

Friedman, J. R., and Voeltz, G. K. (2011). The ER in 3D: a multifunctional dynamic membrane network. Trends Cell Biol. 21, 709-717. doi: 10.1016/j.tcb.2011. 07.004

Futatsugi, A., Kato, K., Ogura, H., Li, S. T., Nagata, E., Kuwajima, G., et al. (1999). Facilitation of NMDAR-independent LTP and spatial learning in mutant mice lacking ryanodine receptor type 3 . Neuron 24, 701-713. doi: 10.1016/S08966273(00)81123-X

Galante, M., and Marty, A. (2003). Presynaptic ryanodine-sensitive calcium stores contribute to evoked neurotransmitter release at the basket cell-Purkinje cell synapse. J. Neurosci. 23, 11229-11234.

Garaschuk, O., Yaari, Y., and Konnerth, A. (1997). Release and sequestration of calcium by ryanodine-sensitive stores in rat hippocampal neurones. J. Physiol. 502(Pt 1), 13-30. doi: 10.1111/j.1469-7793.1997.013bl.x

Gomis, A., Burrone, J., and Lagnado, L. (1999). Two actions of calcium regulate the supply of releasable vesicles at the ribbon synapse of retinal bipolar cells. J. Neurosci. 19, 6309-6317.

Gordon, G. R., and Bains, J. S. (2005). Noradrenaline triggers multivesicular release at glutamatergic synapses in the hypothalamus. J. Neurosci. 25, 11385-11395. doi: 10.1523/JNEUROSCI.2378-05.2005

Goutman, J. D., and Glowatzki, E. (2011). Short-term facilitation modulates size and timing of the synaptic response at the inner hair cell ribbon synapse. J. Neurosci. 31, 7974-7981. doi: 10.1523/JNEUROSCI.0604-11.2011

Grant, L., Slapnick, S., Kennedy, H., and Hackney, C. (2006). Ryanodine receptor localisation in the mammalian cochlea: an ultrastructural study. Hear. Res. 219, 101-109. doi: 10.1016/j.heares.2006.06.002

He, L., Xue, L., Xu, J., Mcneil, B. D., Bai, L., Melicoff, E., et al. (2009). Compound vesicle fusion increases quantal size and potentiates synaptic transmission. Nature 459, 93-97. doi: 10.1038/nature07860

Heidelberger, R., Sterling, P., and Matthews, G. (2002). Roles of ATP in depletion and replenishment of the releasable pool of synaptic vesicles. J. Neurophysiol. 88, 98-106.

Hendricson, A. W., and Guth, P. S. (2002). Transmitter release from Rana pipiens vestibular hair cells via mGluRs: a role for intracellular $\mathrm{Ca}^{(++)}$release. Hear. Res. 172, 99-109. doi: 10.1016/S0378-5955(02)00519-1

Hua, S. Y., Nohmi, M., and Kuba, K. (1993). Characteristics of $\mathrm{Ca}^{2+}$ release induced by $\mathrm{Ca}^{2+}$ influx in cultured bullfrog sympathetic neurones. J. Physiol. 464, 245 272 .

Jackman, S. L., Choi, S. Y., Thoreson, W. B., Rabl, K., Bartoletti, T. M., and Kramer, R. H. (2009). Role of the synaptic ribbon in transmitting the cone light response. Nat. Neurosci. 12, 303-310. doi: 10.1038/nn.2267

Johnson, S. L., Beurg, M., Marcotti, W., and Fettiplace, R. (2011). Prestin-driven cochlear amplification is not limited by the outer hair cell membrane time constant. Neuron 70, 1143-1154. doi: 10.1016/j.neuron.2011. 04.024

Kantardzhieva, A., Liberman, M. C., and Sewell, W. F. (2013). Quantitative analysis of ribbons, vesicles, and cisterns at the cat inner hair cell synapse: correlations with spontaneous rate. J. Comp. Neurol. 521, 3260-3271. doi: 10.1002/cne. 23345

Kato, B. M., and Rubel, E. W. (1999). Glutamate regulates IP3-type and CICR stores in the avian cochlear nucleus. J. Neurophysiol. 81, 1587-1596.

Katz, B., and Miledi, R. (1968). The role of calcium in neuromuscular facilitation. J. Physiol. 195, 481-492.

Katz, B., and Miledi, R. (1969). Tetrodotoxin-resistant electric activity in presynaptic terminals. J. Physiol. 203, 459-487.

Kennedy, H. J. (2002). Intracellular calcium regulation in inner hair cells from neonatal mice. Cell Calcium 31, 127-136. doi: 10.1054/ceca.2001.0267

Kennedy, H. J., and Meech, R. W. (2002). Fast $\mathrm{Ca}^{2+}$ signals at mouse inner hair cell synapse: a role for $\mathrm{Ca}^{2+}$-induced $\mathrm{Ca}^{2+}$ release. J. Physiol. 539, 15-23. doi: 10.1113/jphysiol.2001.013171

Krijnse-Locker, J., Parton, R. G., Fuller, S. D., Griffiths, G., and Dotti, C. G. (1995). The organization of the endoplasmic reticulum and the intermediate compartment in cultured rat hippocampal neurons. Mol. Biol. Cell 6, 1315-1332. doi: $10.1091 / \mathrm{mbc} \cdot 6 \cdot 10.1315$

Krizaj, D., Bao, J. X., Schmitz, Y., Witkovsky, P., and Copenhagen, D. R. (1999). Caffeine-sensitive calcium stores regulate synaptic transmission from retinal rod photoreceptors. J. Neurosci. 19, 7249-7261.

Krizaj, D., Lai, F. A., and Copenhagen, D. R. (2003). Ryanodine stores and calcium regulation in the inner segments of salamander rods and cones. J. Physiol. 547, 761-774. doi: 10.1113/jphysiol.2002.035683

Krizaj, D., Liu, X., and Copenhagen, D. R. (2004). Expression of calcium transporters in the retina of the tiger salamander (Ambystoma tigrinum). J. Comp. Neurol.475, 463-480. doi: 10.1002/cne.20170

Kuba, K. (1994). $\mathrm{Ca}^{(2+)}$-induced $\mathrm{Ca}^{2+}$ release in neurones. Jpn. J. Physiol. 44, 613-650. doi: 10.2170/jjphysiol.44.613

Kwan, C. Y., and Putney, J. W. Jr. (1990). Uptake and intracellular sequestration of divalent cations in resting and methacholine-stimulated mouse lacrimal acinar cells. Dissociation by $\mathrm{Sr}^{2+}$ and $\mathrm{Ba}^{2+}$ of agonist-stimulated divalent cation entry from the refilling of the agonist-sensitive intracellular pool. J. Biol. Chem. 265, 678-684.

Lanner, J. T., Georgiou, D. K., Joshi, A. D., and Hamilton, S. L. (2010). Ryanodine receptors: structure, expression, molecular details, and function in calcium release. Cold Spring Harb. Perspect. Biol. 2, a003996. doi: 10.1101/cshperspect.a003996

Lee, S., Briklin, O., Hiel, H., and Fuchs, P. (2007). Calcium-dependent inactivation of calcium channels in cochlear hair cells of the chicken. J. Physiol. 583, 909-922. doi: 10.1113/jphysiol.2007.135582

Lelli, A., Perin, P., Martini, M., Ciubotaru, C. D., Prigioni, I., Valli, P., et al. (2003). Presynaptic calcium stores modulate afferent release in vestibular hair cells. J. Neurosci. 23, 6894-6903.

Levitan, E. S. (2008). Signaling for vesicle mobilization and synaptic plasticity. Mol. Neurobiol. 37, 39-43. doi: 10.1007/s12035-008-8014-8013

Linton, J. D., Holzhausen, L. C., Babai, N., Song, H., Miyagishima, K. J., Stearns, G. W., et al. (2010). Flow of energy in the outer retina in darkness and in light. Proc. Natl. Acad. Sci. U.S.A. 107, 8599-8604. doi: 10.1073/pnas.1002 471107

Lioudyno, M., Hiel, H., Kong, J. H., Katz, E., Waldman, E., ParameshwaranIyer, S., et al. (2004). A "synaptoplasmic cistern" mediates rapid inhibition of cochlear hair cells. J. Neurosci. 24, 11160-11164. doi: 10.1523/JNEUROSCI.367404.2004

Llano, I., Gonzalez, J., Caputo, C., Lai, F. A., Blayney, L. M., Tan, Y. P., et al. (2000). Presynaptic calcium stores underlie large-amplitude miniature IPSCs and spontaneous calcium transients. Nat. Neurosci. 3, 1256-1265. doi: 10.1038/ 81781

Mammano, F., Frolenkov, G. I., Lagostena, L., Belyantseva, I. A., Kurc, M., Dodane, V., et al. (1999). ATP-Induced $\mathrm{Ca}^{(2+)}$ release in cochlear outer hair cells: localization of an inositol triphosphate-gated $\mathrm{Ca}^{(2+)}$ store to the base of the sensory hair bundle. J. Neurosci. 19, 6918-6929.

Marcotti, W., Johnson, S. L., and Kros, C. J. (2004). Effects of intracellular stores and extracellular $\mathrm{Ca}^{(2+)}$ on $\mathrm{Ca}^{(2+)}$-activated $\mathrm{K}^{(+)}$currents in mature mouse inner hair cells. J. Physiol. 557, 613-633. doi: 10.1113/jphysiol.2003.060137 
Mehta, B., Ke, J. B., Zhang, L., Baden, A. D., Markowitz, A. L., Nayak, S., et al. (2014). Global $\mathrm{Ca}^{2+}$ signaling drives ribbon-independent synaptic transmission at rod bipolar cell synapses. J. Neurosci. 34, 6233-6244. doi: 10.1523/JNEUROSCI.532413.2014

Mercurio, A. M., and Holtzman, E. (1982). Smooth endoplasmic reticulum and other agranular reticulum in frog retinal photoreceptors. J. Neurocytol. 11, 263293. doi: 10.1007/BF01258247

Moser, T., Brandt, A., and Lysakowski, A. (2006). Hair cell ribbon synapses. Cell Tissue Res. 326, 347-359. doi: 10.1007/s00441-006-0276-273

Narita, K., Akita, T., Osanai, M., Shirasaki, T., Kijima, H., and Kuba, K. (1998). A Ca ${ }^{2+}$-induced $\mathrm{Ca}^{2+}$ release mechanism involved in asynchronous exocytosis at frog motor nerve terminals. J. Gen. Physiol. 112, 593-609. doi: 10.1085/jgp.112.5.593

Neher, E. (1998). Vesicle pools and $\mathrm{Ca}^{2+}$ microdomains: new tools for understanding their roles in neurotransmitter release. Neuron 20, 389-399. doi: 10.1016/S0896-6273(00)80983-6

Nishiyama, M., Hong, K., Mikoshiba, K., Poo, M. M., and Kato, K. (2000). Calcium stores regulate the polarity and input specificity of synaptic modification. Nature 408, 584-588. doi: 10.1038/35046067

Oertner, T. G., Sabatini, B. L., Nimchinsky, E. A., and Svoboda, K. (2002). Facilitation at single synapses probed with optical quantal analysis. Nat. Neurosci. 5, 657-664. doi: $10.1038 / \mathrm{nn} 867$

Parekh, A. B. (2008). $\mathrm{Ca}^{2+}$ microdomains near plasma membrane $\mathrm{Ca}^{2+}$ channels: impact on cell function. J. Physiol. 586, 3043-3054. doi: 10.1113/jphysiol.2008.153460

Peng, A. W., Effertz, T., and Ricci, A. J. (2013). Adaptation of mammalian auditory hair cell mechanotransduction is independent of calcium entry. Neuron 80,960 972. doi: 10.1016/j.neuron.2013.08.025

Penner, R., and Neher, E. (1988). The role of calcium in stimulus-secretion coupling in excitable and non-excitable cells. J. Exp. Biol. 139, 329-345.

Perin, P., Botta, L., Tritto, S., and Laforenza, U. (2012). Expression and localization of ryanodine receptors in the frog semicircular canal. J. Biomed. Biotechnol. 398398. doi: 10.1155/2012/398398

Plotkin, J. L., Shen, W., Rafalovich, I., Sebel, L. E., Day, M., Chan, C. S., et al. (2013). Regulation of dendritic calcium release in striatal spiny projection neurons. J. Neurophysiol. 110, 2325-2336. doi: 10.1152/jn.00422.2013

Qin, Z., Zhou, X., Gomez-Smith, M., Pandey, N. R., Lee, K. F., Lagace, D. C., et al. (2012). LIM domain only 4 (LMO4) regulates calcium-induced calcium release and synaptic plasticity in the hippocampus. J. Neurosci. 32, 4271-4283. doi: 10.1523/JNEUROSCI.6271-11.2012

Quinlan, M. E., and Hirasawa, M. (2013). Multivesicular release underlies short term synaptic potentiation independent of release probability change in the supraoptic nucleus. PLoS ONE 8:e77402. doi: 10.1371/journal.pone.0077402

Reyes, M., and Stanton, P. K. (1996). Induction of hippocampal long-term depression requires release of $\mathrm{Ca}^{2+}$ from separate presynaptic and postsynaptic intracellular stores. J. Neurosci. 16, 5951-5960.

Rose, C. R., and Konnerth, A. (2001). Stores not just for storage. Intracellular calcium release and synaptic plasticity. Neuron 31, 519-522. doi: 10.1016/S08966273(01)00402-0

Rossi, M. L., Prigioni, I., Gioglio, L., Rubbini, G., Russo, G., Martini, M., et al. (2006). IP3 receptor in the hair cells of frog semicircular canal and its possible functional role. Eur. J. Neurosci. 23, 1775-1783. doi: 10.1111/j.1460-9568.2006. 04708.x

Savic, N., and Sciancalepore, M. (1998). Intracellular calcium stores modulate miniature GABA-mediated synaptic currents in neonatal rat hippocampal neurons. Eur. J. Neurosci. 10, 3379-3386. doi: 10.1046/j.1460-9568.1998.00342.x

Schnee, M. E., Castellano-Munoz, M., Kong, J. H., Santos-Sacchi, J., and Ricci, A. J. (2011a). Tracking vesicle fusion from hair cell ribbon synapses using a high frequency, dual sine wave stimulus paradigm. Commun. Integr. Biol. 4, 785-787.

Schnee, M. E., Santos-Sacchi, J., Castellano-Munoz, M., Kong, J. H., and Ricci, A. J. (2011b). Calcium-dependent synaptic vesicle trafficking underlies indefatigable release at the hair cell afferent fiber synapse. Neuron 70, 326-338. doi: 10.1016/j.neuron.2011.01.031

Schnee, M. E., Castellano-Munoz, M., and Ricci, A. J. (2013). Response properties from turtle auditory hair cell afferent fibers suggest spike generation is driven by synchronized release both between and within synapses. J. Neurophysiol. 110, 204-220. doi: 10.1152/jn.00121.2013
Schnee, M. E., and Ricci, A. J. (2003). Biophysical and pharmacological characterization of voltage-gated calcium currents in turtle auditory hair cells. J. Physiol. 549, 697-717. doi: 10.1113/jphysiol.2002.037481

Seward, E. P., Chernevskaya, N. I., and Nowycky, M. C. (1996). $\mathrm{Ba}^{2+}$ ions evoke two kinetically distinct patterns of exocytosis in chromaffin cells, but not in neurohypophysial nerve terminals. J. Neurosci. 16, 1370-1379.

Shakiryanova, D., Tully, A., Hewes, R. S., Deitcher, D. L., and Levitan, E. S. (2005). Activity-dependent liberation of synaptic neuropeptide vesicles. Nat. Neurosci. 8, 173-178. doi: 10.1038/nn1377

Sharma, G., and Vijayaraghavan, S. (2003). Modulation of presynaptic store calcium induces release of glutamate and postsynaptic firing. Neuron 38, 929-939. doi: 10.1016/S0896-6273(03)00322-2

Shmigol, A., Verkhratsky, A., and Isenberg, G. (1995). Calcium-induced calcium release in rat sensory neurons. J. Physiol. 489(Pt 3), 627-636.

Simkus, C. R., and Stricker, C. (2002). The contribution of intracellular calcium stores to mEPSCs recorded in layer II neurones of rat barrel cortex. J. Physiol. 545, 521-535. doi: 10.1113/jphysiol.2002.022103

Singer, J. H., Lassova, L., Vardi, N., and Diamond, J. S. (2004). Coordinated multivesicular release at a mammalian ribbon synapse. Nat. Neurosci. 7, 826-833. doi: $10.1038 / \mathrm{nn} 1280$

Sitsapesan, R., and Williams, A. J. (1990). Mechanisms of caffeine activation of single calcium-release channels of sheep cardiac sarcoplasmic reticulum. J. Physiol. 423, 425-439.

Snellman, J., Mehta, B., Babai, N., Bartoletti, T. M., Akmentin, W., Francis, A., et al. (2011). Acute destruction of the synaptic ribbon reveals a role for the ribbon in vesicle priming. Nat. Neurosci. 14, 1135-1141. doi: 10.1038/nn.2870

Soga-Sakakibara, S., Kubota, M., Suzuki, S., Akita, T., Narita, K., and Kuba, K. (2010). Calcium dependence of the priming, activation and inactivation of ryanodine receptors in frog motor nerve terminals. Eur. J. Neurosci. 32, 948-962. doi: 10.1111/j.1460-9568.2010.07381.x

Sridhar, T. S., Brown, M. C., and Sewell, W. F. (1997). Unique postsynaptic signaling at the hair cell efferent synapse permits calcium to evoke changes on two time scales. J. Neurosci. 17, 428-437.

Stern, M. D. (1992). Theory of excitation-contraction coupling in cardiac muscle. Biophys. J. 63, 497-517. doi: 10.1016/S0006-3495(92)81615-81616

Stern, M. D., Song, L. S., Cheng, H., Sham, J. S., Yang, H. T., Boheler, K. R., et al. (1999). Local control models of cardiac excitation-contraction coupling. A possible role for allosteric interactions between ryanodine receptors. J. Gen. Physiol. 113, 469-489. doi: 10.1085/jgp.113.3.469

Stevens, C. F., and Wesseling, J. F. (1998). Activity-dependent modulation of the rate at which synaptic vesicles become available to undergo exocytosis. Neuron 21, 415-424. doi: 10.1016/S0896-6273(00)80550-4

Storozhuk, M. V., Ivanova, S. Y., Balaban, P. M., and Kostyuk, P. G. (2005). Possible role of mitochondria in posttetanic potentiation of GABAergic synaptic transmission in rat neocortical cell cultures. Synapse 58, 45-52. doi: 10.1002/syn.20186

Suryanarayanan, A., and Slaughter, M. M. (2006). Synaptic transmission mediated by internal calcium stores in rod photoreceptors. J. Neurosci. 26, 1759-1766. doi: 10.1523/JNEUROSCI.3895-05.2006

Szikra, T., Barabas, P., Bartoletti, T. M., Huang, W., Akopian, A., Thoreson, W. B., et al. (2009). Calcium homeostasis and cone signaling are regulated by interactions between calcium stores and plasma membrane ion channels. PLOS ONE 4:e6723. doi: 10.1371/journal.pone.0006723

Szikra, T., Cusato, K., Thoreson, W. B., Barabas, P., Bartoletti, T. M., and Krizaj, D. (2008). Depletion of calcium stores regulates calcium influx and signal transmission in rod photoreceptors. J. Physiol. 586, 4859-4875. doi: 10.1113/jphysiol.2008.160051

Szikra, T., and Krizaj, D. (2006). The dynamic range and domain-specific signals of intracellular calcium in photoreceptors. Neuroscience 141, 143-155. doi: 10.1016/j.neuroscience.2006.03.054

Szikra, T., and Krizaj, D. (2007). Intracellular organelles and calcium homeostasis in rods and cones. Vis. Neurosci. 24, 733-743. doi: 10.1017/S09525238070 70587

Tang, Y., and Zucker, R. S. (1997). Mitochondrial involvement in post-tetanic potentiation of synaptic transmission. Neuron 18, 483-491. doi: 10.1016/S08966273(00)81248-9

Thoreson, W. B. (2007). Kinetics of synaptic transmission at ribbon synapses of rods and cones. Mol. Neurobiol. 36, 205-223. doi: 10.1007/s12035-007-0019-9 
Tong, G., and Jahr, C. E. (1994). Multivesicular release from excitatory synapses of cultured hippocampal neurons. Neuron 12, 51-59. doi: 10.1016/08966273(94)90151-1

Tse, F. W., Tse, A., Hille, B., Horstmann, H., and Almers, W. (1997). Local Ca ${ }^{2+}$ release from internal stores controls exocytosis in pituitary gonadotrophs. Neuron 18, 121-132. doi: 10.1016/S0896-6273(01)80051-9

Tucker, T., Art, J. J., and Fettiplace, R. (1996). Routes of calcium entry and extrusion in turtle hair cells. Ann. N. Y. Acad. Sci. 781, 123-137. doi: 10.1111/j.17496632.1996.tb15697.x

Tucker, T., and Fettiplace, R. (1995). Confocal imaging of calcium microdomains and calcium extrusion in turtle hair cells. Neuron 15, 1323-1335. doi: 10.1016/0896-6273(95)90011-X

Ungar, F., Piscopo, I., and Holtzman, E. (1981). Calcium accumulation in intracellular compartments of frog retinal rod photoreceptors. Brain Res. 205, 200-206. doi: 10.1016/0006-8993(81)90733-2

Ungar, F., Piscopo, I., Letizia, J., and Holtzman, E. (1984). Uptake of calcium by the endoplasmic reticulum of the frog photoreceptor. J. Cell Biol. 98, 1645-1655. doi: 10.1083/jcb.98.5.1645

Unni, V. K., Zakharenko, S. S., Zablow, L., Decostanzo, A. J., and Siegelbaum, S. A (2004). Calcium release from presynaptic ryanodine-sensitive stores is required for long-term depression at hippocampal CA3-CA3 pyramidal neuron synapses. I. Neurosci. 24, 9612-9622. doi: 10.1523/JNEUROSCI.5583-03.2004

Usachev, Y. M., and Thayer, S. A. (1997). All-or-none $\mathrm{Ca}^{2+}$ release from intracellular stores triggered by $\mathrm{Ca}^{2+}$ influx through voltage-gated $\mathrm{Ca}^{2+}$ channels in rat sensory neurons. J. Neurosci. 17, 7404-7414.

Verkhratsky, A. (2005). Physiology and pathophysiology of the calcium store in the endoplasmic reticulum of neurons. Physiol. Rev. 85, 201-279. doi 10.1152/physrev.00004.2004

Voets, T., Neher, E., and Moser, T. (1999). Mechanisms underlying phasic and sustained secretion in chromaffin cells from mouse adrenal slices. Neuron 23 607-615. doi: 10.1016/S0896-6273(00)80812-0

von Ruden, L., and Neher, E. (1993). A Ca-dependent early step in the release of catecholamines from adrenal chromaffin cells. Science 262, 1061-1065. doi: $10.1126 /$ science.8235626

Wan, Q. F., Nixon, E., and Heidelberger, R. (2012). Regulation of presynaptic calcium in a mammalian synaptic terminal. J. Neurophysiol. 108, 3059-3067. doi: 10.1152/jn.00213.2012
Wan, Q. F., Zhou, Z. Y., Thakur, P., Vila, A., Sherry, D. M., Janz, R., et al. (2010). SV2 acts via presynaptic calcium to regulate neurotransmitter release. Neuron 66 , 884-895. doi: 10.1016/j.neuron.2010.05.010

Wang, L. Y., and Kaczmarek, L. K. (1998). High-frequency firing helps replenish the readily releasable pool of synaptic vesicles. Nature 394, 384-388. doi: $10.1038 / 28645$

Weisz, C. J., Lehar, M., Hiel, H., Glowatzki, E., and Fuchs, P. A. (2012). Synaptic transfer from outer hair cells to type II afferent fibers in the rat cochlea. J. Neurosci. 32, 9528-9536. doi: 10.1523/JNEUROSCI.619411.2012

Zenisek, D., and Matthews, G. (2000). The role of mitochondria in presynaptic calcium handling at a ribbon synapse. Neuron 25, 229-237. doi: 10.1016/S08966273(00)80885-5

Zhang, C., Wu, B., Beglopoulos, V., Wines-Samuelson, M., Zhang, D., Dragatsis, I., et al. (2009). Presenilins are essential for regulating neurotransmitter release. Nature 460, 632-636. doi: 10.1038/nature08177

Zhu, M. X., Ma, J., Parrington, J., Calcraft, P. J., Galione, A., and Evans, A. M. (2010). Calcium signaling via two-pore channels: local or global, that is the question. Am. J. Physiol. Cell Physiol. 298, C430-C441. doi: 10.1152/ajpcell.004 75.2009

Zucker, R.S. (1989). Short-term synaptic plasticity. Annu. Rev. Neurosci. 12, 13-31. doi: 10.1146/annurev.ne.12.030189.000305

Conflict of Interest Statement: The authors declare that the research was conducted in the absence of any commercial or financial relationships that could be construed as a potential conflict of interest.

Received: 28 March 2014; accepted: 28 May 2014; published online: 12 June 2014 Citation: Castellano-Muñoz M and Ricci AJ (2014) Role of intracellular calcium stores in hair-cell ribbon synapse. Front. Cell. Neurosci. 8:162. doi: 10.3389/fncel.2014.00162 This article was submitted to the journal Frontiers in Cellular Neuroscience. Copyright (C) 2014 Castellano-Muñoz and Ricci. This is an open-access article distributed under the terms of the Creative Commons Attribution License (CC BY). The use, distribution or reproduction in other forums is permitted, provided the original author(s) or licensor are credited and that the original publication in this journal is cited, in accordance with accepted academic practice. No use, distribution or reproduction is permitted which does not comply with these terms. 